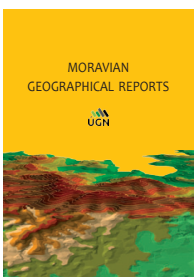

\title{
The role of manufacturing in the development of rural regions: Evidence from a highly industrialised Moravian region
}

\author{
Jan ŽENKA ${ }^{\text {a }}$, Simona ŠŤASTNÁ a ${ }^{\text {, Adam PAVLÍK }}{ }^{\text {a }}$
}

\begin{abstract}
Various types of manufacturing firms located in rural municipalities are identified in this paper, and we determine the intensity of their economic linkages at the local and regional levels. We also examine the factors affecting the intensity of local/regional sourcing and purchasing. Due to the unavailability of detailed economic data at the municipal level, our research draws on a case study of 26 rural manufacturing small/medium-sized enterprises located in the Zlin Region in the eastern part of the Czech Republic. As a highly industrialised region, Zlin should theoretically provide a very favourable environment for the development of local/regional productive linkages of rural manufacturing firms. Several non-parametric tests have been employed to test the effects of firm size, age, industry and location, on the intensity of local and regional purchasing/sourcing. We found the most common firms are those that purchase and sell mostly on a regional (NUTS3) level rather than on the local level. Small firms source and sell more locally than larger firms. Effects of the firm age, industry and location, on the intensity of local/regional sourcing and purchasing were not confirmed.
\end{abstract}

Keywords: manufacturing, rural regions, local sourcing, backward linkages, forward linkages, Zlin Region, Czech Republic

Article history: Received 20 April 2020, Accepted 25 September 2020, Published 31 March 2021

\section{Introduction}

The traditional rural economy has long been associated with primary economic activities, seen predominantly in its production function (Dinis, 2006). Over the last four decades, restructuring (see Woods, 2005) has brought about major economic changes in rural regions, amongst which we can list:

i. A reduction of the share of agriculture in employment/ production as a result of technological innovations and moving towards a rural consumption function (Halfacree, 2006);

ii. A transition shift of the part of industry and services from urban to rural areas (Keeble and Tyler, 1995; Bosworth and Finke, 2019), resulting in an industrial structure of the rural economy closer to that of cities;

iii. The decline of part of the manufacturing capacities in traditional rural manufacturing industries (food, textile, glass, wood processing, etc.) associated with shifting employment to technology-intensive industries engaged in manufacturing fields, such as automotive parts or electronics (Fløysand and Sjøholt, 2007); and iv. Economic globalisation manifested by, among other factors, changes in the ownership structure of rural manufacturing firms in favour of a growing share of foreign capital.

One of the manifestations of economic globalisation (see e.g. Kalantaridis, 2005; Woods, 2013) in developed countries is the increasing linkages and interdependence of the economies of urban and rural regions (Lichter and Brown, 2011; Mayer et al., 2016; Bosworth and Venhorst, 2018). Paradoxically, however, in many cases, the supplier-customer linkages (hereinafter referred to as "economic linkages") of manufacturing firms at the local level are weakened: between the urban areas and the rural hinterland, and also between local rural firms mutually (Czarnecki, 2015). The products of local rural entrepreneurs are pushed out of local urban markets by imports from largescale standardised production.

Rural manufacturing firms, on the other hand, in order to achieve economies of scale, must integrate into global production networks (Coe et al., 2015). They often focus on the production of highly specialised components for

\footnotetext{
a Department of Human Geography and Regional Development, University of Ostrava, Czech Republic (*corresponding author: J. Ženka; e-mail: jan.zenka@osu.cz)
} 
multinational corporations, usually based in (foreign) metropolitan regions. Rural firms rarely find a sufficiently large market or competent suppliers at the local level (Crone and Watts, 2003).

We focus on Czech rural regions that are highly industrialised (Vaishar and Štastná, 2019) and export oriented. Intensive local economic relationships of manufacturing firms can be another important source of employment and income (see below). For this reason, we analyse two types of economic linkages that can stimulate the development of rural economies (Courtney et al., 2008): supplier ("backward") linkages and customer ("forward") linkages. ${ }^{1}$ Our goal is to determine: a) what types of manufacturing firms are developing in Czech rural communities in terms of the geography of economic linkages; b) the intensity of economic linkages at the local/ regional level that these manufacturing firms create; and c) what factors influence the intensity of local economic linkages of rural manufacturing firms.

Given the absence of relevant economic data on rural municipalities, we evaluate economic linkages based on a case study of 26 manufacturing firms in rural municipalities of the Zlín Region. Rural municipalities of the Zlín Region have on average the second-highest share of manufacturing industry in employment after the Moravian-Silesian Region (Business Register, 2017). The Zlín Region achieves the highest share of employment in manufacturing industry among all Czech regions. The Zlín countryside is characterised by population continuity, industrial tradition, social capital (Pileček and Jančák, 2010), a high degree of specialisation in the manufacturing of fabricated metal products and technologically related industries, as well as a high density of small-sized manufacturing firms in the above sectors. Because of this, it has, according to the theoretical background (see section 3), very good conditions for the development of intensive economic relationships of manufacturing firms at the local level.

In the following section, we briefly characterise the relationships between local linkages of manufacturing firms and the development of rural regions. In the subsequent section, we discuss the intensity factors of local economic linkages of the manufacturing firms in rural regions, while the fourth section describes specifics of the restructuring of the Czech countryside after 1989. The fifth and sixth sections discuss the distribution and the industrial structure of the manufacturing industry in the Czech Republic and in the Zlín Region. The seventh section presents methods and data sources, followed by a discussion of the empirical results. In the conclusion, we summarise and discuss the main findings.

\section{Local economic linkages of manufacturing firms and rural development}

The spatial level of economic linkages among firms in the manufacturing industry (hereinafter referred to as manufacturing firms) is crucial for the development of rural regions. According to net income theory (Persky, 1993; Courtney et al., 2008) derived from the original economic base model (see Illeris, 2005, for a summary of the research), regional economic growth is the coefficient of export income and a regional multiplier, minus the outflow of income from the region due to import (Persky, 1993). Therefore, economic growth not only depends on the inflow of income from other regions due to the export activity of manufacturing industry, agriculture and other "basic" industries (see Illeris, 2005, pp. 448-449), but also on the intensity of local economic linkages and the presence of non-basic industries serving the local market (e.g. consumer services) that prevent income outflow from a particular rural region.

According to the spatial configuration of economic linkages, rural manufacturing firms can be divided into four main types: domestic, dependent, propelling and extravert. The table below (Tab. 1) and the descriptions of individual firm types are based on a simplified adaptation of the Romero and Santos typology (2007) and divide firms by their predominant linkages to local or external suppliers and customers.

Domestic firms are usually small entities that mainly buy and sell at the local level. These entities prevent the outflow of profits from the region (Illeris, 2005) and generate local multipliers, but their overall contribution to regional development is limited due to the absence of strong export linkages. One advantage may be the interconnection of local production systems and a contribution to the formation of a diversified network of suppliers, a source of localisation economies.

Dependent firms buy on the external market and sell on the local market. This increases dependency on external entities and does not create any important multipliers. These firms bring the least benefit to rural economies, especially in low technology-intensive industries. They can contribute to local business productivity, however, through technology transfer, sophisticated components and/or efficient manufacturing processes through business contacts and unintended knowledge spillovers (see Pavlínek and Žižžalová, 2016).

Propelling firms that sell to other regions and buy locally provide the strongest impulses for the development of rural economies. Because of their exports, they bring profit to the region, which is multiplied by intensive local supply linkages and the resulting strong local multiplier (Courtney et al., 2008).

Extravert firms buy and sell outside the local market. Although they can contribute with a relatively large profit into rural municipalities because of their exports, a considerable amount will flow out to other localities as a result of weak local economic linkages. This may not only be dis-embedded branch plants of multinational corporations (Sonn and Lee, 2012), but also endogenously formed smallsized firms that extend beyond the local context with their economic linkages (Romero and Santos, 2007).

\begin{tabular}{lcc}
\hline & Local suppliers & External suppliers \\
\hline Local customers & Domestic firm & Dependent firm \\
External customers & Propelling firm & Extravert firm \\
\hline
\end{tabular}

Tab. 1: Typology of rural manufacturing firms by economic linkages.

Source: Romero and Santos (2007); authors' interpretation

\footnotetext{
${ }^{1}$ For the overall intensity of these relationships at the local level, we define as the degree of local integration of manufacturing companies. Local relationships are such economic relationships that do not cross the administrative boundaries of the administrative district of the municipality with extended powers. For the purpose of this paper, we define rural municipalities by the population criterion of 3,000, according to the Act on Municipalities No. 128/200 Coll.
} 
This typology is somewhat simplistic and indicative (Müller and Korsgaard, 2018). In addition to distinguishing between only four idealised firm types, it focuses only on the material linkages of manufacturing firms: it does not include, for example, innovation cooperation, linkages to local institutions, knowledge spillovers, and many other relevant relationships at the local level (Lang et al., 2014). Despite all of these factors, it can be used for the input classification of firms in terms of their potential benefits for the development of rural municipalities. Individual types of firms develop depending on several corporate, sectoral and regional characteristics, which will be discussed in the next section.

\section{Factors affecting the intensity of local economic linkages of manufacturing firms in rural regions}

Factors affecting the spatial level of supply and customer relationships of manufacturing firms in rural regions can be distinguished into three basic groups: firm, industry, and regional characteristics (see Tab. 2).

The most important firm characteristics affecting the degree of local integration include the size, ownership, and history of a given firm (Courtney et al., 2008). Small firms generally create more intensive local supply (Courtney and Errington, 2000; Arndt and Sternberg, 2000; Romero and Santos, 2007) and customer linkages (Crone and Watts, 2003), as large firms have found it difficult to find firms at the local level capable of delivering in the required volume, while the local market is not big enough for them. Therefore, with the increasing firm size, the share of extravert firms should grow, while small manufacturing firms are more often either domestic or dependent.

According to some authors (Dobson, 1985; Courtney and Errington, 2000), ownership affects the spatiality of economic linkages. Independent (domestic) firms source more locally than their foreign-owned counterparts that have geographically more extensive networks of contacts. Branch plants of transnational corporations should be generally more extravert than other economic subjects (see Sonn and Lee, 2012). Several other results, however, do not confirm this assertion (Perkmann, 2006; Courtney et al., 2008).

The history of the establishment and development of a firm in a given location affects the scale of supplier and customer linkages in various ways. Mills (2002) documented the negative relationship between the intensity of local linkages and the geographical distance of the firm from the owner's/manager's home. Resident-based firms tend

\begin{tabular}{ll}
\hline Factor & Mechanism \\
\hline Firm & \\
Size & $\begin{array}{l}\text { Small firms are more locally integrated (higher share of domestic and dependent firms), whereas large } \\
\text { firms are often extravert, because the rural region does not offer adequate suppliers or a sufficiently large } \\
\text { market. }\end{array}$ \\
& $\begin{array}{l}\text { Domestic firms create more intensive economic linkages at the local level than international firms that } \\
\text { have more contacts in other regions and states. Independent firms are more locally integrated than } \\
\text { Ownership }\end{array}$ \\
& $\begin{array}{l}\text { "Younger/manufacturing plants of firms based in other regions. } \\
\text { integrated at the local level due to inertia and/or social embeddedness. }\end{array}$
\end{tabular}

\section{Industry (sector) and product}

Ubiquity

Linkages to rural industries

Technology intensity

Product standardisation

Region

Location

City/region size

Supplier base

Firm size structure
Industries characterised by a large number of small firms scattered, among other things, in rural areas, are characterised by a higher degree of local integration than industries with high levels of size and territorial concentration.

Industrial firms linked to agriculture, forestry, fishing or other typically rural activities, demonstrate intense local economic linkages.

Firms in less technologically intensive industries are more closely interconnected with local suppliers/ customers that are available in rural areas.

A higher level of local integration is typical for firms manufacturing non-standardised custom-made products that need intensive personal contacts with customers/suppliers.

With increasing distance from the city/town, the rate of the local economic integration of rural industrial firms (and the share of domestic firms) increases.

Rural industrial firms in the hinterland of large cities are more locally integrated than firms in the hinterland of smaller towns due to the effect of urbanisation economies. With decreasing population size of the municipality, the share of domestic firms should decrease.

Firms in regions specialised in the same/related sectors are more locally integrated than firms in regions with different specialisation.

Firms in regions with a large number of small/medium-sized enterprises in the given industry benefit more from localisation economies and are more locally integrated than those in regions with the dominant position of a single large corporation.

Tab. 2: Selected factors of the intensity of local economic linkages of industrial firms in rural regions

Sources: Courtney et al., 2008; Courtney and Errington, 2000; Dobson, 1985; Courtney and Errington, 2000; Perkmann, 2006; Akgün et al., 2011; North and Smallbone, 1996; Crone and Watts, 2003; Amin and Malmberg, 1992; Tavares and Young, 2006; Pavlinek and Ženka, 2016; Mitchell, 2005; Meijers and Burger, 2017; Krugman and Venables, 1995; Parr, 2002; Drucker, 2013; Drucker and Feser, 2012; Chinitz, 1961; Romero and Santos, 2007 
to purchase more from their vicinity than firms founded by immigrants from urban regions (Akgün et al., 2011; Courtney et al., 2008). The duration of the business activity of the firm in a given location has an ambiguous influence. Some authors document the local focus of the linkages of newly created companies, which subsequently geographically expand the network of supplier-customer linkages (North and Smallbone, 1996). Other studies show the higher intensity of local linkages in "older" firms due to learning effects: the search for and cultivation of relations with local suppliers (Crone and Watts, 2003). Endogenous firms newly established in the region or split off from local firms, should be more closely linked to the local economy than firms created by an enterprise investment from another region or state. This may be due to the inertia and social embeddedness of endogenous firms, as well as the fact that external firms entering the rural region build upon existing supplier-customer relationships with entities outside the rural region (Courtney et al., 2008; Habersetzer, 2017).

Factors at the industry/product level have the least unambiguous impact on the spatial level of supplier-customer linkages of manufacturing firms. Manufacturing industry (especially export-oriented) creates on average weaker supplier and customer relationships at the local and regional level compared to consumer and commercial services (HirschKreinsen, 2008; Květoň and Šafr, 2019) or the construction industry (Courtney et al., 2008). The main reason is the unavailability of supplies and also insufficient demand for manufacturing products, usually produced in large volumes. In manufacturing, the intensity of local linkages, in general, should be greater in the following sectors (an adaptation of the Crone and Watts, 2003 typology):

a. "Ubiquitous" sectors characterised by the territorial dispersion of a large number of (often small) firms in rural regions: in the Czech Republic, this is the case, for example, of the manufacturing of fabricated metal products and engineering industries, or the manufacturing of less-complex automotive parts;

b. Industries linked to rural production activities: e.g. the food-processing industry linked to agriculture or the wood-processing industry linked to forestry;

c. The production of simpler and less technologically intensive products for which it is realistic to find intermediate product suppliers in rural areas and/or which have a low unit price and thus expensive transport costs over longer distances; and

d. Custom-made, non-standardised products that require intense personal contacts with suppliers, thus benefitting from the geographical proximity of suppliers (Amin and Malmberg, 1992; Glückler et al., 2020).

On the other side of the spectrum, there is largescale production of standardised products, and then, on the contrary, the production of highly specialised and sophisticated products in highly globalised sectors such as automotive, electronics, and pharmaceuticals (Tavares and Young, 2006). Such is also the case for material/energyintensive or other sectors purchasing, in particular, mineral raw materials (Courtney et al., 2008) that are extremely unevenly distributed and may not be available in the given rural region (petrochemical industry - oil; rubber industry - natural rubber; plastics - granulates; production of wire cables - copper): see Pavlínek and Ženka (2016).

The third group of factors are regional characteristics, which include the distance of a rural firm from a nearby city ('municipality with extended powers' - hereinafter 'MEP' or regional capital), city size, the industrial specialisation of the rural region, the number and size-structure of firms in the given industry, reflecting the intensity of local competition (Courtney et al., 2008). With an increasing distance of rural communities from urban centres, the intensity of local economic linkages and the share of domestic firms increases (Courtney and Errington, 2000; Mitchell, 2005). On the other hand, intense local linkages can be expected in the hinterland of large cities that can produce higher local multipliers (Persky, 1993), due to agglomeration economies and the positive "effect of borrowed size" in their commuting hinterlands (Courtney et al., 2008; Meijers and Burger, 2017). The large differentiated market creates demand for rural hinterland products, allows for a higher degree of specialisation of supplier firms - hence contributing to the development, productivity and diversity of the local supply base, and thus to the intensity of local supplier linkages (Krugman and Venables, 1995). Sharing local suppliers and intensive local supplier linkages are one of the mechanisms of localisation economies that strengthen the clustering of firms in the locality (Parr, 2002), and stimulates the growth of domestic and propelling firms. The reverse effect also applies, however: territorial concentration and the geographical proximity of a large number of firms may strengthen local supplier linkages between firms in the particular industry (Sohn, 2004).

To achieve local integration, a large number of (small and medium-sized) enterprises in the researched industry is more favourable than one large company. In regions with one large dominant firm, smaller economic entities in the same industry achieve lower localisation economies (sharing of suppliers, skilled labour, knowledge, public assets such as infrastructure, etc.: Parr, 2002) than entities in regions with a less concentrated size structure of enterprises (Drucker, 2013). Large dominant firms are more likely to form linkages at national or (sub)-global levels. Local suppliers prefer large stable contracts with dominant firms and often offer their tailor-made products/ services only to these firms, not willing/able to deliver to small local rural firms (Drucker and Feser, 2012). The actual number and size of firms, however, do not mechanically affect the intensity of localisation economies and local economic linkages. The historical continuity of population and economy, institutional thickness, local culture, regional identity, social capital and numerous other factors can play a crucial role in such cases. Important factors of local economic integration include the historical trajectory of the development and specialisation of the regional economy. Rural firms active in the same (or a technologically related) sector in which the particular region has specialised for a long time (Crone and Watts, 2003), may be more closely linked to local firms and markets.

To summarise, the regional historical, cultural, and institutional context has a major impact on the intensity of local economic linkages. For this reason, the following section is devoted to the specifics of restructuring the Czech rural economy with a focus on the Zlín Region.

\section{Restructuring of the economy in Czech rural regions -focusing on the Zlín region}

In the Czech Republic, the process of restructuring the rural economy started in the early 1990s, that is, with some delay compared to developed Western European countries. 
The nature of the process was significantly influenced by the inherited organisational and industrial structure of the rural economy, which, despite a profound transformation in the 1990s, has affected the character of Czech rural industry to this day. Between 1989 and 2000, economically active population in agriculture dropped to one-third (Bičík and Jančák, 2005). An important mechanism for the development of rural industry during the transformation period was the outsourcing of entities from the nationalised unified farmers' cooperatives (collective farms), which, in addition to dominant agricultural production, also dealt in many cases with affiliated industrial production, repair activities, construction work or services (Majerová, 2017; Jančák et al., 2019): these non-agricultural activities accounted for $27 \%$ of employment in the agricultural sector (Swinnen et al., 2001).

In parallel, a deindustrialisation process was underway in the $1990 \mathrm{~s}$, affecting mainly towns and rural unemployment through the weakening of work commuting more than the loss of jobs directly in the countryside (Jančák et al., 2019). Nevertheless, manufacturing has become a major production sector in most rural regions, including the Zlín region (see Fig. 1). In 2017, the manufacturing industry, in the group of Czech municipalities with fewer than 3,000 residents, accounted for almost one-quarter of the jobs. In the same year, it accounted for $29 \%$ of employment in rural municipalities of the Zlin Region ${ }^{2}$, which was the secondhighest industrialisation rate in the Czech Republic after the Moravian-Silesian Region (Business Register, 2017).

Rural municipalities in non-metropolitan regions, with large industrial hubs and several peripheral regions mostly in the eastern part of the country (Barboŕik, 2019), are mostly specialised in the manufacturing/secondary sector.
Contrarily, the metropolitan hinterlands of Prague, Ostrava, and other regional cities are the least specialised in this type of industry (Fig. 1).

The first decade of the $21^{\text {st }}$ century can be described as a period of reindustrialisation (Koutský, 2011), which had very selective territorial impacts (Hruška and Píša, 2019). Reindustrialisation was mostly driven by economic globalisation, associated with the integration of enterprises into global production networks, and the inflow of foreign direct investment to both existing and newly built production facilities. The inflow of foreign capital in many rural regions compensated for job losses (especially in traditional labourintensive industries) associated with the deindustrialisation of the 1990s (Hruška and Píša, 2019). Another manifestation (also at the national level) was a shift in industrial structure towards a higher representation of capital-intensive industries and an increasing specialisation in the automotive and supply industries (Toušek and Šerý, 2013). Integration into the automotive production networks has been especially important in the Zlín region, characterised by a relatively high share of traditional (medium-low) tech manufacturing industries and/or links to primary sector activities such as agriculture or forestry (Fig. 2).

Because of the reorientation to the supply for the automotive industry, traditional (medium) low-tech industries in the Zlín Region have survived. Manufacturing of fabricated metal products holds the key economic position (see also Novák and Ježíková, 2016). Wood processing, rubber and plastics, furniture, clothing and, to a lesser extent, the food processing industry, have a higher share of employment compared to other Czech regions (Fig. 2). Intensive local economic linkages in these industries (and to technologically related industries) can be expected.

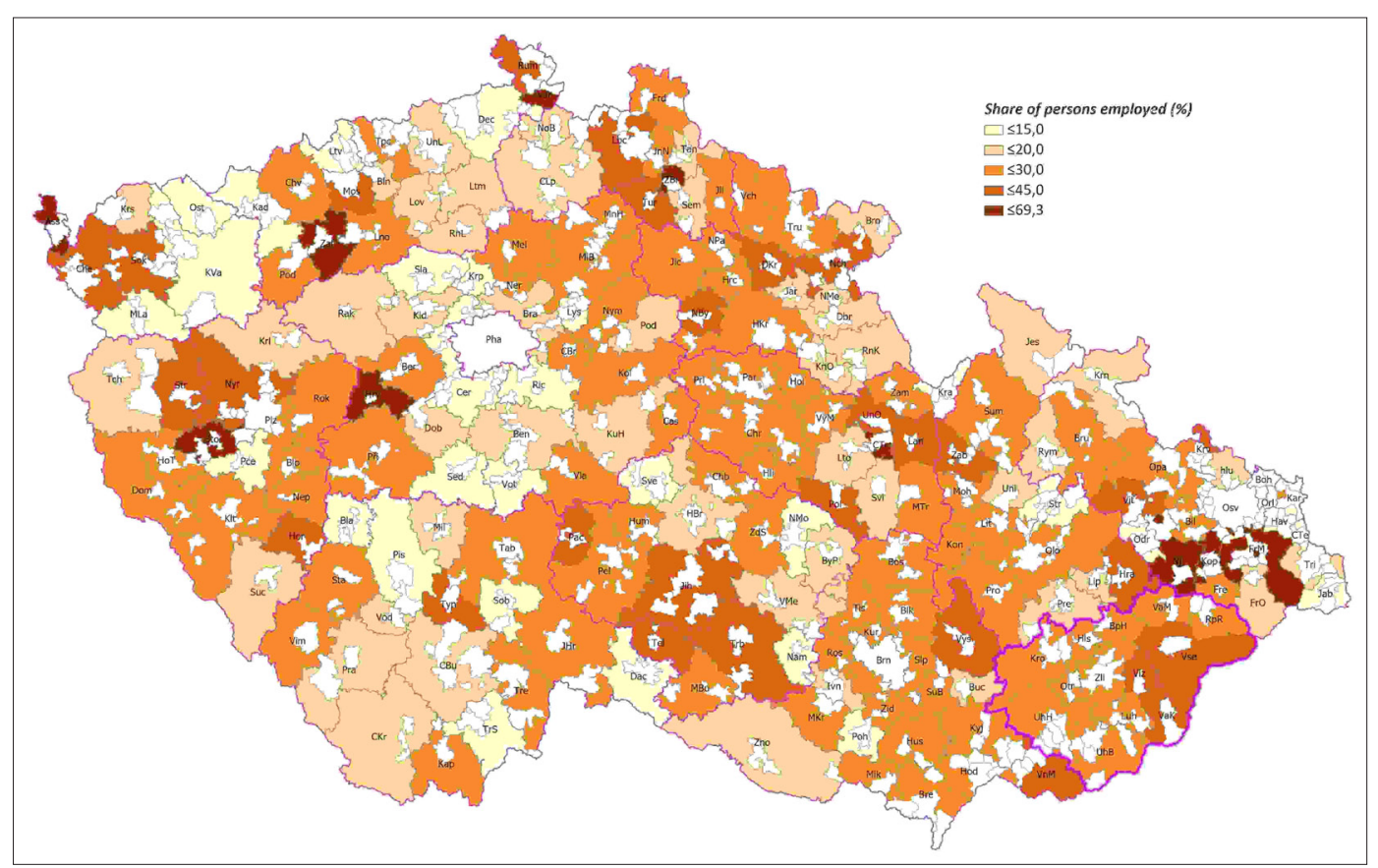

Fig. 1: Proportion of manufacturing industry in the employment rate of rural municipalities in 2017 (aggregated at microregional level: "AD MEP"; administrative districts of the Zlin Region are marked purple) Source: Ženka and Pavlík, 2019

\footnotetext{
${ }^{2}$ At the municipal level, peripheral areas of the Zlín Region are situated in: (1) the southeastern part of the territory close to the border with Slovakia in AD MEP Vsetín, Valašské Klobouky and Uherský Brod (Vaishar and Zapletalová, 2005); (2) the northwestern part of the region, municipalities in AD MEP Uherské Hradiště and Kroměříž (Perlín et al., 2010). At a microregional level, peripheral areas are AD MEP Valašské Klobouky, Luhačovice, Holešov and Bystřice pod Hostýnem (Ženka et al., 2017).
} 


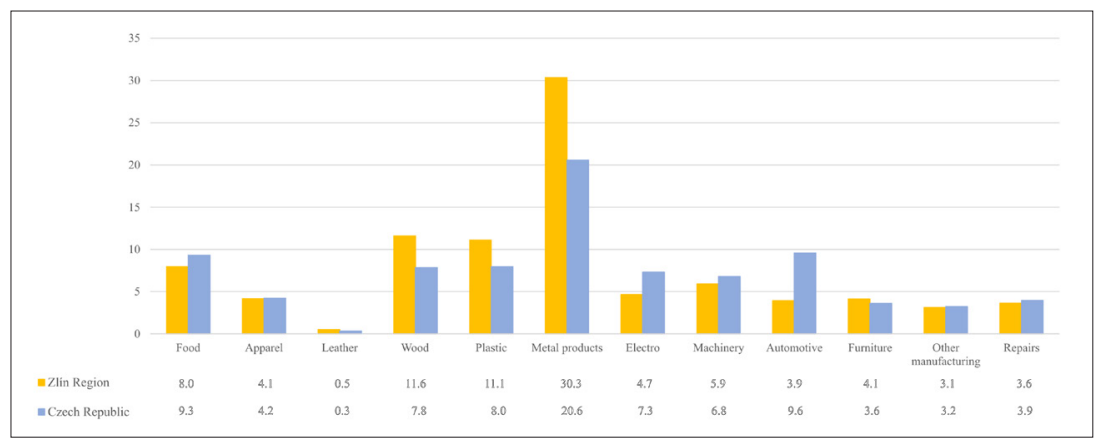

Fig. 2: Employment structure in the manufacturing industry of rural municipalities: comparison of the Czech Republic and the Zlin Region in 2017 (\%). Source: Business Register, 2017

Note: Food =10; Apparel =14; Leather =15; Wood =16; Plastic = 22; Metal products = 25; Electro = 27; Machinery = 28; Automotive = 29; Furniture = 31; Other manufacturing = 32; $33=$ Repairs. The NACE rev. 2.0 taxonomy was used, https://ec.europa.eu/eurostat/documents/3859598/5902521/KS-RA-07-015-EN.PDF

One must also consider, however, that Czech rural and nonmetropolitan regions, in general, have been characterised by relatively weak economic linkages at the local level (Ženka et al., 2015). This phenomenon can be explained historically by the interruption of traditions of private businesses and entrepreneurship in rural areas in the socialist era, and by the forced integration of many rural industrial enterprises into large, state-owned, vertically organised industrial companies (Heidenreich, 1994; Slach, 2011). These centrally managed state-owned enterprises were usually based in metropolitan regions, with many subordinate production plants with minimal strategic functions in small and medium-sized towns. The privatisation of such former production and economic units into the hands of Czech or foreign entities, and the restructuring and integration into global production networks of multinational corporations (Pavlínek, 2004), was one of the important mechanisms of rural industry development after 1989. In several Czech regions, however, the pattern of de-regionalised production has been replicated, and new hollow clusters have been developed, this time involving the production plants of multinational corporations (Ženka et al., 2014, 2015). This trend has been less pronounced in the Zlín Region, given its relatively strong path-dependence and long-term continuity in industrial structure and localisation (see Ženka et al., 2017).

The restructuring of industry in rural areas was also influenced by processes of residential and commercial suburbanisation (for more details, see Sýkora and Ouředníček, 2007) and counterurbanisation (for a topical introduction see Keeble and Tyler, 1995; Šimon, 2011; Bosworth, 2019). Commercial suburbanisation/ counterurbanisation processes include not only the physical relocation of manufacturing firms from towns to the countryside, but also the establishment of new manufacturing firms in the countryside by 'urban immigrants' (North, 1998). Empirical evidence of the nature and intensity of commercial suburbanisation and counterurbanisation in the Czech Republic, in relation to the development of manufacturing industry, is very limited (for initial overviews, see Hruška and Píša, 2019; Píša and Hruška, 2019). The most visible manifestations of such processes include the construction of production halls and logistics centres in urban hinterlands (Hruška, Konečný, 2011), as well as the establishment of industrial zones (Kunc, 2006).

These processes, however, are probably rather driven by the inflow of foreign direct investment rather than by the relocation of industry from urban to rural areas. It can be assumed that the impact of entrepreneurs moving from towns and cities to the establishment of rural manufacturing firms in the Czech Republic, will be significantly smaller than in Western European countries (e.g. the United Kingdom, the Netherlands), for which relatively extensive empirical evidence of the urban-rural shift process is available (Keeble and Tyler, 1995; Bosworth, 2019). It can also be assumed that the effects of commercial suburbanisation on the development of rural industries in the Zlín Region are limited, considering its relatively low population density and the medium-sized regional capital (80,000 inhabitants in 2020).

Rural areas of the Zlín Region are characterised by a long-term stability in terms of settlement, religiosity, and an overall high intensity of social and cultural capital (Pileček and Jančák, 2010), that might be supportive for the creation of local/regional economic linkages. In terms of its local economic base profile, there is a prevalence of diversified industrial and peripheral regions (Ženka et al., 2017), with only the Otrokovice and Uherský Brod communities as exceptions due to the presence of one large dominant manufacturing firm. All rural regions in the Zlín Region can be defined as industrialised rural localities when using the typology proposed by Hruška and Píša (2019). Most of them demonstrate a relatively good economic performance in the national context (Ženka and Wellisch, 2019), confirming the finding of Bole et al. (2020, p. 23) that small and medium-sized industrial towns/ regions are not necessarily disadvantaged concerning their socioeconomic performance.

The current spatial distribution and structure of rural manufacturing in the Zlín region result primarily from the following factors/changes: (1) the development of the shoe manufacturing industry (Bata Shoe Company) and the path-branching of technology-related industries, especially rubber and later the plastics industries (Bednář, 1970); (2) the state-controlled concentration of the arms industry; (3) the socialist industrialisation following upon the interwar period (see Kunc, 2006), developing, in addition to the above-mentioned sectors, the chemical industry, electrical engineering, aircraft and other industries; and (4) the reorientation of a part of the traditional industries after 1990 to supplies for the automotive industry, and the inflow of foreign direct investment from the production of automotive components (spearheaded by tyre production: see Ženka and Pavlínek, 2013; Blažek and Kuncová, 2011). Industrial development in the Zlín region is characterised by the continuity of several major industries (except for leather products) and diversification into technologically related 
industries, rather than by a radical change of industrial structure and any importation of completely new unrelated industries. Therefore, the intensive local and regional economic linkages in traditional manufacturing industries in the Zlín region (mostly in the manufacturing of fabricated metal products) are to be expected.

\section{Data and methods}

For this paper, municipalities with a population of less than 3,000 are considered rural, therefore we use a descriptive definition based on the Act No. 128/2000 Coll. on Municipalities. The proportion of manufacturing industry in the employment rate (Fig. 2) in rural areas was calculated using data provided by the Business Register (BR, 2017), as the product of the number of firms in the given size category and the mean of the given size category (e.g. employment in 10 firms in the size category of 50-99 employees were estimated as $10 \times 74.5$, i.e. 745 employees). Rural municipalities were spatially aggregated to the level of administrative districts of municipalities with extended powers (AD MEP), excluding municipalities with the population over 3,000 people in the area of the given district) to quantify employment in the manufacturing industry for these territorial units. We decided to include only manufacturing firms (codes 10-33 according to NACE rev. 2.0), which had this type of activity listed as first (in the list of economic activities provided by the Business Register).

Another source of primary data was a semi-structured interview. Between 2016 and 2019, we conducted 26 interviews with business owners or their authorised representatives (names of companies in the text have been changed). When selecting the firms, we opted for the method of deliberate (purposive) sampling. The selection was made in such a way that the addressed firms represented a wide range of manufacturing industries, but the emphasis was put on a greater representation of firms involved in the manufacturing of fabricated metal products (Fig. 3). The sample is not representative from the statistical point of view, but it reflects industrial and size structure of Czech rural manufacturing and captures the most important types of manufacturing firms located in Czech rural municipalities see the section 6 and 7 . While current sourcing patterns of rural manufacturing firms in other Czech or foreign regions may differ from our sample in the Zlín Region, various sourcing strategies of rural manufacturing firms in relation to their size, industry, mode of entry and growth.

The first part of the interviews was focused on collecting basic information about the surveyed firm: number of employees, main products, date and mode of firm establishment, and the educational structure of employees. The interview was made up of questions to identify key suppliers, customers and competitors, and to estimate the share of local, regional, national/central European, European and global linkages in the total value of purchases and sales. We also inquired about the presence of firms in the same industry in that particular locality, and their possible positive and negative impacts on the local labour market, knowledge dissemination, development of the supplier base and infrastructure. The important parts of the interviews were the respondent's narratives focusing on the establishment and development of the product portfolio, technologies, standards and linkages at various scales. Those mostly unstandardised pieces of information allowed us to understand how various factors affect the spatial nature of production linkages.

We evaluated the collected data using frequency response analysis and content analysis. Because the interviews included also standardised questions and quantitative

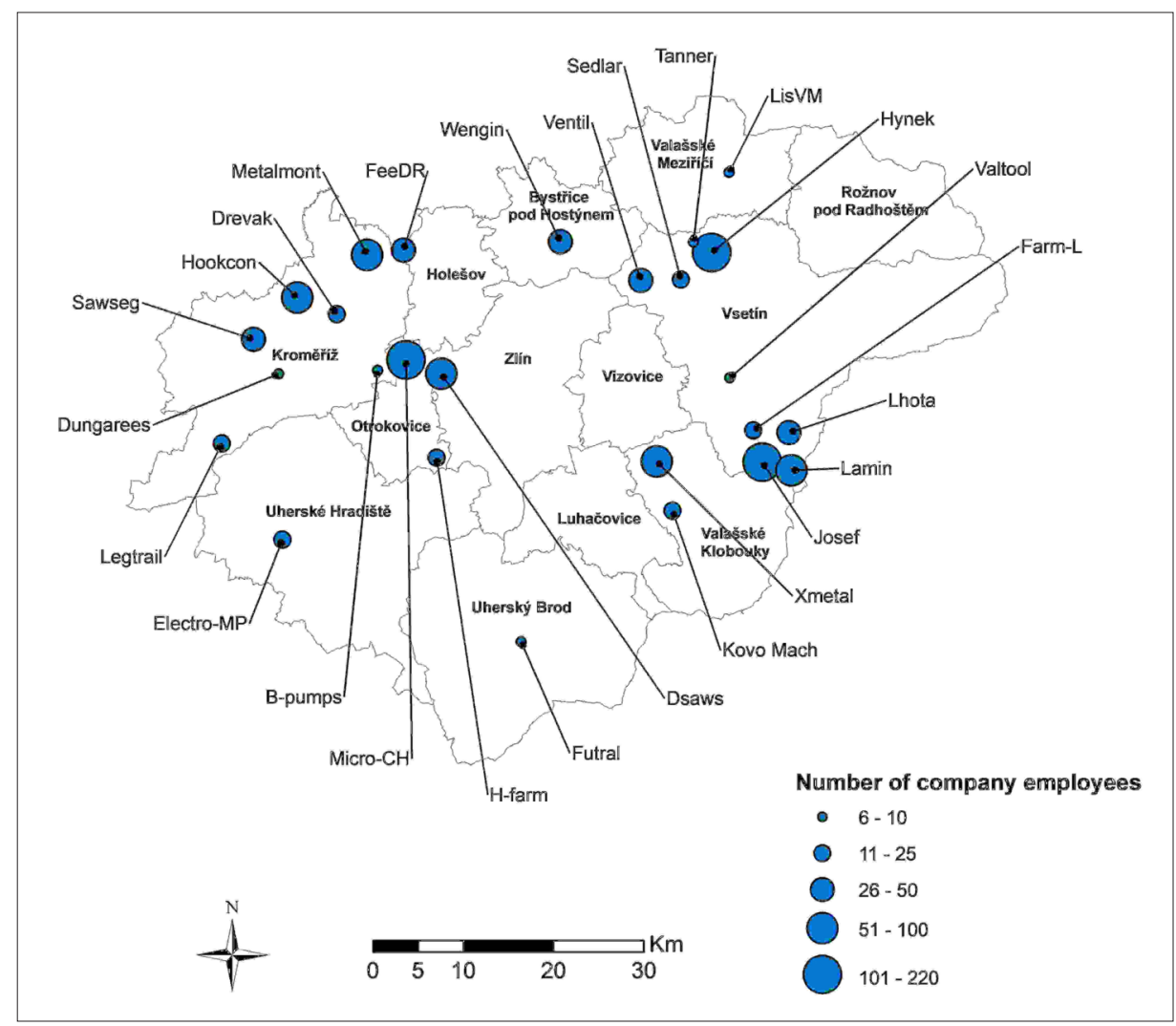

Fig. 3: Localisation of the companies interviewed in the Zlin Region (company names are fictional) Source: authors' compilation 


\begin{tabular}{|c|c|c|}
\hline Variable & Description & Data source \\
\hline $\begin{array}{l}\text { Local/regional supplier/customer } \\
\text { (binary) }\end{array}$ & $\begin{array}{l}\text { 1: the firm purchases/sells at least } 10 \% \text { of the value of total purchases/ } \\
\text { sale locally (AD MEP)/regionally (NUTS3); } 0 \text { : less than } 10 \%\end{array}$ & Author survey \\
\hline Firm size & Number of persons employed in the firm & Business Register 2017 \\
\hline Firm age & $\begin{array}{l}\text { Categories according to the period of establishment: } 1 \text { : } 1951-1999 ; 2 \text { : } \\
2000-2019\end{array}$ & Author survey \\
\hline Industry (binary) & Manufacturing of fabricated metal products (1) or other industry (0) & Business Register 2017 \\
\hline Accessibility & Population size of the MEP divided by the mileage from the given firm & CSO 2017; The Time Now \\
\hline Establishment (binary) & $\begin{array}{l}\text { Outsourcing from a local firm in the same/related industry (1) or } \\
\text { another way of establishment }(0) \text {. }\end{array}$ & Author survey \\
\hline
\end{tabular}

Tab. 3: Variables and indicators employed in the statistical tests

Source: authors' survey

indicators, we carried out several non-parametric statistical tests of the effect of selected independent variables on the intensity of linkages at the local and regional level (see Tab. 3). Results should be interpreted with caution. Some of them might have failed to reject the null hypothesis due to the small sample size $(\mathrm{N}=26)$ and firm heterogeneity (in terms of employment, industry and ownership), not because of the non-existence of the relationships. Simple and robust statistical tests of roughly aggregated data were used only to supplement the qualitative analysis, providing not conclusive but indicative results that might indicate possible avenues of future research.

The intensity of production linkages was evaluated at the following scales:

a. Local: inside the administrative district of the municipality with extended powers (AD MEP); divided into local rural (rural municipalities in the AD MEP) and the local city (MEP);

b. Regional: linkages in the respective NUTS3 region;

c. Central European: Czech Republic, Slovakia, Poland, Austria and Germany;

d. European: at least one country outside Central Europe; and

e. Global: at least one country outside Europe.
Given that rural manufacturing firms in the sample are generally small in terms of employment, we employed the following definition of small, medium-sized and large enterprises: (i) Large: more than 100 persons employed; (ii) Medium-sized: 20-99 persons employed; and (iii) Small: less than 20 persons employed.

In the next section we present the empirical results of the survey of 26 managers of manufacturing firms in rural areas of the Zlín Region.

\section{Results}

Of the 26 companies examined, 12 were established in the transformation period in the first half of the 1990s and another 9 in the first decade of the $21^{\text {st }}$ century. Small and medium-sized enterprises prevail as only 3 of the addressed firms employed more than 100 employees (Tab. 4). Almost half of the workers had a secondary education without a secondary school leaving examination; one third had it with this exam. As firms grow in size, the proportion of workers with primary or secondary education without a secondary school leaving exam decreases and the proportion of university graduates increases. Ten firms were engaged in the manufacturing of fabricated metal products, and the remainder (except for one engineering and one chemical enterprise) were in low- and lower-tech industries.

\begin{tabular}{lcc}
\hline Null hypothesis & Test & p-value \\
\hline The distribution of Employment is the same across categories of Local-suppliers. & Mann-Whitney U & 0.068 \\
The distribution of Employment is the same across categories of Regional-suppliers. & Mann-Whitney U & 0.860 \\
The distribution of Employment is the same across categories of Local-customers. & Mann-Whitney U & 0.029 \\
The distribution of Employment is the same across categories of Regional-customers. & Mann-Whitney U & 0.278 \\
Variables Firm-age and Local-suppliers-binary are statistically independent. & chi-square test & 0.320 \\
Variables Firm-age and Local-customers-binary are statistically independent. & chi-square test & 0.315 \\
Variables Firm-age and Regional-suppliers-binary are statistically independent. & chi-square test & 0.234 \\
Variables Firm-age and Regional-customers-binary are statistically independent. & chi-square test & 0.612 \\
The distribution of Accessibility is the same across categories of Regional-suppliers. & Mann-Whitney U & 0.020 \\
The distribution of Accessibility is the same across categories of Regional-customers. & Mann-Whitney U & 0.138 \\
The distribution of Regional-suppliers-share is the same across categories of Industry. & Mann-Whitney U & 0.623 \\
The distribution of Regional-customers-share is the same across categories of Industry. & Mann-Whitney U & 0.698 \\
Variables Establishment and Local-suppliers are statistically independent. & chi-square test & 0.263 \\
Variables Local-suppliers-binary and Local-customers are statistically independent. & chi-square test & 0.191 \\
\hline
\end{tabular}

Tab. 4: Selected results of the statistical tests. Source: authors' calculations

Note: The significance level is 0.05 in all cases. Significant relationships are marked in bold. Results of the tests not listed in Table 4 were not statistically significant 
Nearly all firms were established by local entrepreneurs in or near their place of residence, with only one exception of the business shifting from another region (Prague). As we assumed, commercial suburbanisation/counterurbanisation was not an important mechanism of rural manufacturing development in the Zlín Region. A majority of entities were established and developed from local firms operating in the same or technologically related industry before 1989: either by separation of parts of these firms, or by splitting off from associated farmers' cooperative production. Direct links to socialist production are a characteristic for less than one third of companies that use already existing industrial zones or farmers' cooperative areas and have developed by reorganising traditional local industries. 16 respondents stated that their firm was established as "new" in the research locality. In fact, in almost all of these cases, it is possible to trace some type of historical link, for example through the employer's education in a given field or his/her previous employment in a firm operating in the same or a technologically related sector.

Most companies created supplier-customer relationships at multiple scales at the same time and were independent of a single business partner or at the local market only (Tab. 5). They tended to create economic linkages more with the local city than the surrounding rural municipalities. In terms of production volume, purchases and sales at the regional level were the most significant, with a total of $59 \%$ of the purchase value and $66 \%$ of the sales value being made in the Zlín Region or close to it. Central European purchases were a characteristic for midsize companies (metal working, plastics industry) that purchased material not available locally. The global linkages were rather an exception - only one company (Dungarees) made purchases almost exclusively at the global level.

At the local level, companies generally could not find asufficiently large market, so the proportion of sales in thelocal rural hinterland to total sales was very low. The exceptions were companies combining industrial and construction activities: Metalmont specialising in the production of metal structures and construction of prefabricated steel halls or joinery, and the construction company Drevak. The local cities are also not an important market for the products of manufacturing firms. In most cases, firms do not produce final products that could be sold and used in an urban market; their customers are other (industrial) firms, often located outside the region. Again, there are exceptions, such as the Dungarees workwear manufacturer or the toolmaker Valtool with a key customer at the local level: a Japanese company supplying car pyrotechnic airbag initiators.

For most firms, key customers are located in the region, which is again in line with the findings of a previous study on the neighbouring South Moravian Region carried out by Štastná (2011). Customers at the transnational level were identified by 17 (mostly older) companies, which were linked to mainly Central European markets. These were mainly manufacturers of highly specific components for further industrial processing or machining. One example is Ventil supplying among other things fans for the automotive industry and the manufacturer of metal legs for Legtrail trailers. Customers of these companies are dispersed, resulting in supra-regional customer relationships. An interesting example is the Hynek paint shop, where the focus on the (Central) European market is explained by the linkage to major customers - large prestigious multinational corporations in the automotive industry and railway engineering.
The results of statistical tests (see Tab. 4) show that with increasing size of companies the share of local purchases and especially sales decrease. Larger companies at the local level have a hard time finding specialised and competent suppliers capable of complete deliveries in the required volume, as well as finding sales in too small and insufficiently diversified markets. This does not apply, however, to the intensity of economic linkages at the regional level, where we have not found any connection with the number of company employees.

Firm size is not the only factor limiting the share of local sourcing. Even more important is the unavailability of local suppliers that might be caused by various factors. In labourintensive manufacturing industries, the local suppliers might have been pushed out by imports from lower cost developing countries, so now the firms have to source internationally. This is the case of the workwear producer Dungarees, with cost motivated import of textile fabrics from Pakistan, India and China. Other examples are firms that source mostly materials either from primary industries (agriculture, forestry, mining) or from highly specific suppliers that can be found in few localities around the world. In our survey, the example is FeeDr, producer of feeds for farm animals, who imported specific remixes and minerals from Latin America and China.

Intensive local or regional sourcing is characteristic for endogeneous firms operating in traditional regional industries, such as the Tanner, a producer of leather gloves and saddlery. More importantly, the mode of establishment and development of the firm might be of key importance for current production linkages. Sawseg, a producer of segment saws, has been (together with several other firms) spun off from the local state-owned producer of saws, Pila, that has survived until today. Although Sawseg has been acquired by a multinational company and integrated into its international value chain, the firm has maintained intensive sourcing linkages and collaboration with local successors of the state-owned company Pila. Continuity of traditional regional specialisation and/or diversification into technologically related industries is conducive for the development of local and regional production linkages.

The company age had no statistically significant effect on purchases or sales. The industry sector seems to have almost no statistical effect - on average, firms manufacturing prefabricated metal products did not differ from firms in other industries in terms of the intensity of local purchases and sales. The geographical distance and town size did not affect the intensity of local purchases or sales, but firms near larger cities had stronger linkages to supply firms in the region than firms in peripheral localities. We have not demonstrated a connection between the intensity of local/ regional purchases and sales - firms that make significant purchases at the local level do not necessarily need to be linked to local markets in terms of sales and vice versa. Nor did we find any differences in the intensity of local economic linkages between the individual micro-regions of the Zlín Region. Therefore, the firm size structure in MEPs had no measurable impact on local/regional purchases/sales of the analysed rural manufacturing firms: the effect of regional industrial dominance (Drucker and Feser, 2013) was therefore not confirmed.

\section{Discussion and conclusions}

Summarising the results so far, it can be argued that in rural municipalities of the Zlín Region domestic and propelling firms prevail, while the least represented are dependent firms 


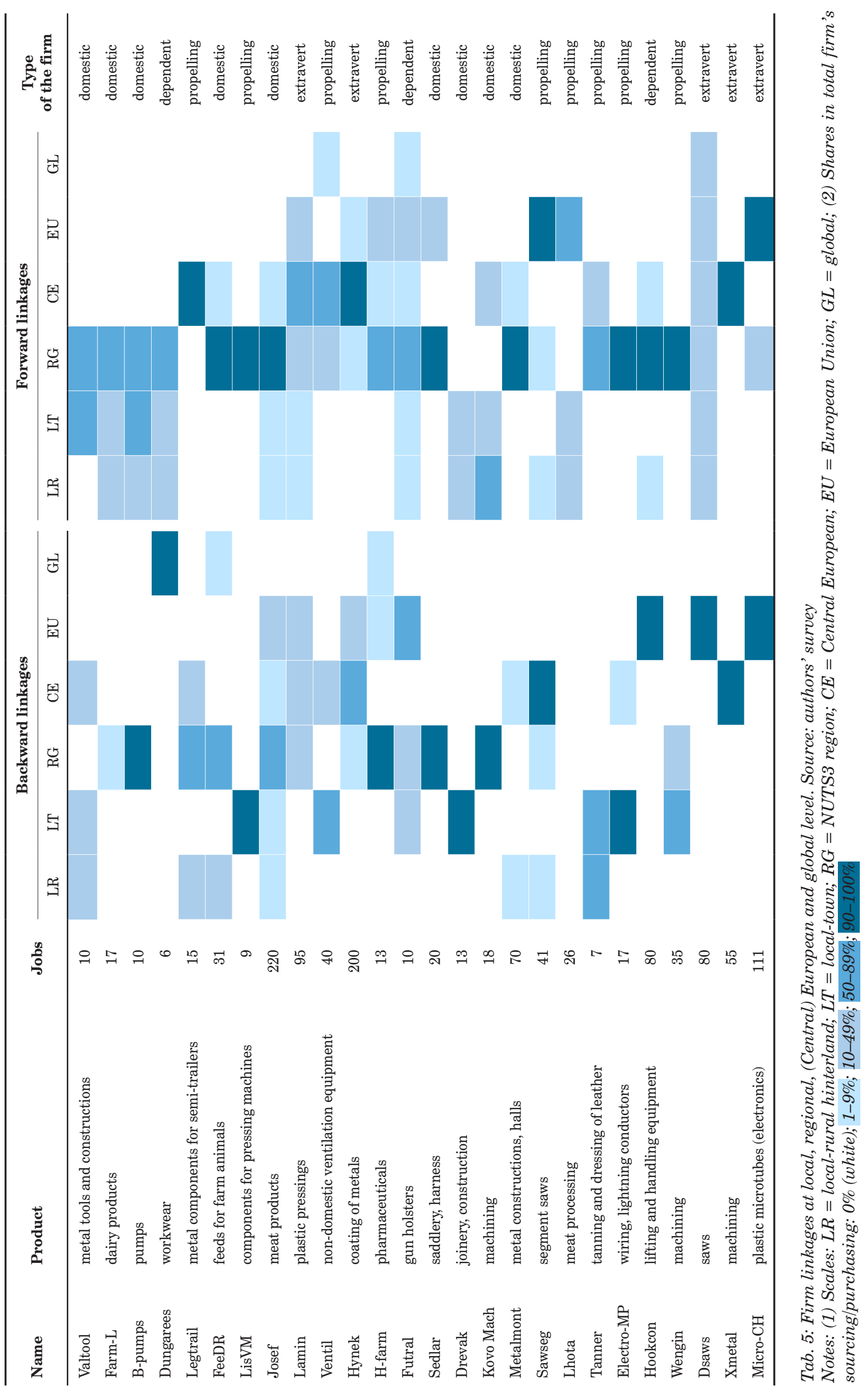


selling mainly regionally (see Tab. 5). Dependent firms buy predominantly at the European or global level - due to lower input prices (in agreement with Courtney et al., 2008) and/ or the unavailability of components in their home region: see also Pavlínek and Ženka (2016). In the second least numerous group one finds the extravert firms that also do not create any intense local/regional linkages, due to the unavailability of components on-site and insufficient local demand. Most of them are in the position of third-tier suppliers of large industrial corporations in technology-intensive sectors of the manufacturing industry (often related to the automotive industry), located at national or (Central) European level. While rural manufacturing firms in the Zlín Region either supply technologically simple components or focus on highly specific custom-tailored products, their prospects of upgrading towards higher value-added products are usually constrained by their small size, limited localised capabilities (see the discussion by Gwosdz et al., 2020) and resources, rather than by power asymmetries in their respective global production networks.

Despite the existence of these firms, we cannot describe most of the (rural) areas of the Zlín Region as "Satellite Platforms" (Markusen, 1996; Ženka et al., 2017), that is, as clusters of locally dis-embedded firms or plants, usually export-oriented and foreign capital-controlled. Neither can they be labelled as Marshallian Industrial Districts (Markusen, 1996), which are characterised by a dense local network of small locally owned firms interconnected by long-term contracts and capitalising on localisation economies. While there is a relatively high rate of spatial clustering of metal manufacturers in the Zlín Region, mutual economic linkages at the local level are surprisingly weak. According to the results of the interviews, local rural manufacturing firms do not benefit significantly from localisation economies resulting from the geographical proximity of firms in the same industry. Empirical evidence from the highly industrialised Zlín Region thus supports previous assumptions of relatively weak local or regional embeddedness of manufacturing firms in the Czech Republic and other Central European industries, while exceptions exist (see Gwosdz et al., 2020, for an analysis of industrial towns in Poland). Apart from the effects of historically de-regionalised production, rural manufacturing firms in the Zlín region exhibit the relatively low intensity of local sourcing due to their integration into many different global production networks. Their principal customers and suppliers are located elsewhere.

Domestic firms are mainly integrated at the regional level, so from the perspective of rural municipalities, we could consider them as an extravert. Propelling firms that are also third-order suppliers tend to sell at (Central) European level to a large extent for the same reason as extravert firms, as they are often linked to large customers in the Czech Republic or (Central) Europe or produce a highly specific product for which there is not enough demand at the local level. A specific type of propelling firms is entities that buy locally and sell mainly regionally.

The above results are almost the opposite of the empirical findings by Romero and Santos (2007) from the peripheral tertiary Spanish region of Andalusia, with a prevalence of dependent and extravert firms (but they were not just rural firms). Based on this and previous evidence (Ženka et al., 2015, 2017), the Zlín Region can be described as a highly industrialised export periphery, characterised by higher business activity, related diversity and a developed regional production system. All of that is evident even though export regions, in general, are characterised by a less intensive regional embeddedness of local firms (Květoň and Šafr, 2019). Most of the analysed rural industrial firms made their purchases and sales mainly at the regional level (in agreement with the findings of Slach, 2011 and Štastna et al., 2011), due to low local demand and lack of relevant suppliers for the production of highly specific products at the local level (Crone and Watts, 2003). We did not identify any monocentric network of economic linkages: rural firms source from various localities in the Zlín Region, not necessarily from the regional capital. Neither did we identify significant supplier/customer linkages of selected rural manufacturing firms to the MEP. This does not mean that economic growth in rural municipalities of the Zlín Region is not driven by the MEP's demand for industrial goods and services (for the theory: see Bosworth and Venhorst, 2017). The economic linkages of the investigated rural manufacturing firms, however, did not follow necessarily the urban-rural (nodal) pattern of economic linkages.

The sample of 26 manufacturing entities allows for only indicative and preliminary statements about the most important factors of the intensity of corporate purchases/ sales at the local/regional level, or a typology of rural manufacturing firms. With a great deal of caution, we can conclude that on average, large corporations buy/sell locally less than small and medium-sized enterprises (see also Crone and Watts, 2003; Courtney et al., 2008; Romero and Santos, 2007). Firms in peripheral and harder-to-access areas purchased less from regional entities (probably because of the focus on highly specific, custom-made products), but they did not significantly differ from firms located near urban areas in terms of the intensity of local supply linkages (contrary to Mitchell, 2005 and Courtney et al., 2008). We failed to demonstrate the effect of other factors at the corporate, sectoral or regional level, such as the age of the firms, the ownership of the firms, the sector/product, the sectoral/size structure of the region, or location. We cannot exclude the possibility, however, that future research into a larger sample of rural industrial firms could reveal the effects of these variables.

This research study has produced some findings that could be used as a base for the formulation of economic and regional policies. It should be considered that for many rural municipalities and regions (not only) in the Czech Republic, the export of industrial products is a key source of income. Thus, local economic linkages can be an important contribution to job creation and added value. Regional and national policymakers, however, often overestimate the benefits for regional development engendered by large foreign-owned industrial firms, which usually have their strongest supply/customer relationships at the (multi)national level.

Our empirical results have demonstrated a relatively weak link between rural firms and firms in MEPs. Although regional capitals and MEPS retain a key impact on the economic development of their surrounding rural communities, nodal regions are integrated through commutation to work and services much less than the economic linkages between rural and urban industrial firms. Therefore, there is a need to support and develop the production, knowledge and other types of linkages of rural industrial enterprises at the relevant scale levels: regional, national and transnational (North and Smallbone, 2006). 


\section{Acknowledgements}

This research was funded by the Czech Science Foundation through the research grant: "Paths development in traditional industries in old industrial regions in Czechia: governance, actors, institutions and leadership", grant number 18-11299S. We also thank Ondřej Slach for helpful comments.

\section{References:}

AKGÜN, A., BAYCAN-LEVENT, T., NIJKAMP, P., POOT, J. (2011): Roles of Local and Newcomer Entrepreneurs in Rural Development: A Comparative Meta-analytic Study. Regional Studies, 45(9): 1207-1223.

AMIN, A., MALMBERG, A. (1992): Competing structural and institutional influences on the geography of production in Europe. Environment and Planning A, 24(3): 401-416.

ARNDT, O., STERNBERG, R. (2000): Do manufacturing firms profit from intraregional innovation linkages? An empirical based answer. European Planning Studies, 8(4): 465-485.

BARBOŘÍK, D. (2019): Sektorová specializace územních jednotek ČR v období ekonomické transformace. (Diploma Thesis). Brno, Masarykova Univerzita.

BEDNÁŘ, K. (1970): Rozmístění průmyslu v českých zemích na počátku 20. století (1902). Academia. Praha.

BIČÍK, I., JANČÁK, V. (2005): Transformační procesy v českém zemědělství po roce 1990. Praha, Univerzita Karlova.

BLAŽEK, J., KUNCOVÁ, I. (2011): Klastry: módní pojem, nebo skutečný zdroj konkurenceschopnosti? Ekonomický časopis, 59(3): 225-241.

BOLE, D., KOZINA, J., TIRAN, J. (2020): The socioeconomic performance of small and medium-sized industrial towns: Slovenian perspectives. Moravian Geographical Reports, 28(1): 16-28.

BOSWORTH, G. (2010): Commercial counterurbanisation: an emerging force in rural economic development. Environment and Planning A, 42(4): 966-981.

BOSWORTH, G., FINKE, B. (2020): Commercial Counterurbanisation: A driving force in rural economic development. Environment and Planning A: Economy and Space, 52(3): 654-674.

BOSWORTH, G., VENHORST, V. (2018): Economic linkages between urban and rural regions-what's in it for the rural? Regional Studies, 52(8): 1075-1085.

BR (2017): Business Register. Praha, Czech Statistical Office.

CHINITZ, B. (1961): Contrasts in agglomeration: New York and Pittsburgh. The American Economic Review, 51(2): 279-289.

COE, N. M., YEUNG, H.W. (2015): Global Production Networks: Theorizing Economic Development in an Interconnected World. Oxford, Oxford University Press.

COURTNEY, P., ERRINGTON, A. (2000): The role of small towns in the local economy and some implications for development policy. Local Economy, 15(4): 280-301.

COURTNEY, P., LÉPICIER, D., SCHMITT, B. (2008): Spatial patterns of production linkages in the context of Europe's small towns: how are rural firms linked to the local economy? Regional Studies, 42(3): 355-374.
CRONE, M., WATTS, H. D. (2003): The Determinants of Regional Sourcing by Multinational Manufacturing Firms: Evidence from Yorkshire and Humberside, UK. European Planning Studies, 11(6): 717-737.

CSO (2017). Public Database. Prague, Czech Statistical Office.

CZARNECKI, A. (2015). The changing role of small towns as sales and supply markets for rural hinterland. In: Zajda, K., Michalska, S. [eds.]: Young Researchers and the Problems of Polish Rural Areas (pp. 147-168). Lódz, University of Lódz.

DINIS, A. (2006): Rural Enterpreneurship: An Inovation and Marketing Perspective. In: Morgan. E. [ed.]: The new European rurality:strategies for small firms (pp. 157-178). Aldershot, Ashgate.

DOBSON, S. M. (1984): An Analysis of the Role of Linkages in Peripheral Area Development: The Case of Devon and Cornwall [PhD Thesis]. Plymouth Polytechnic.

DRUCKER, J. (2013): Industrial structure and the sources of agglomeration economies: evidence from manufacturing plant production. Growth and Change, 44(1): 54-91.

DRUCKER, J., FESER, E. (2012): Regional industrial structure and agglomeration economies: An analysis of productivity in three manufacturing industries. Regional Science and Urban Economics, 42(1-2): 1-14.

FLØYSAND, A., SJØHOLT, P. (2007): Rural development and embeddedness: The importance of human relations for industrial restructuring in rural areas. Sociologia Ruralis 47(3): 205-27.

GLÜCKLER, J., PUNSTEIN, A. M., WUTTKE, C., KIRCHNER, P. (2020): The 'hourglass' model: an institutional morphology of rural industrialism in Baden-Württemberg. European Planning Studies, 28(8): 1554-1574.

GWOSDZ, K., DOMAŃSKI, B., WODECKA, E. B. (2020): Localised capabilities as an intermediating factor in the transition from an old to a new development path: The case of post-socialist industrial towns. Moravian Geographical Reports, 28(2): 124-135.

HIRSH-KREINSEN, H. (2008): "Low-tech" innovations. Industry and innovation, 15(1): 19-43.

HABERSETZER, A. (2017): The role of pre-entry experience of firm founders in peripheral regions: Routines, business contacts, and local starting conditions. Growth and Change, 48(4): 769-786.

HALFACREE, K. (2006): Rural space: constructing a three-fold architecture. In: Cloke, P., Marsden, T., Mooney, P. [eds.]: Handbook of rural studies (pp. 44-62). London, SAGE.

HEIDENREICH, M. (1994): Die mitteleuropäische Großindustrie im Transformationsprozeß. Zeitschrift für Soziologie 23: 3-21.

HRUŠKA, V., KONEČNÝ, O. (2011): Současný venkov v kontextu postproduktivistického přechodu: rozdílné předpoklady konkurenceschopnosti. In: Ježek, J., Kaňka, L. [eds.]: Konkurenceschopnost a udržitelný rozvoj malých měst a venkovských regionů v České republice (pp. 72-80). Plzeň, Západočeská univerzita v Plzni.

HRUŠKA, V., PÍŠA, J. (2019): Winning and losing rural localities of the post-socialist economic restructuring: case study of Czechia. Hungarian Geographical Bulletin, 68(4): 373-389. 
ILLERIS, S. (2005): The role of services in regional and urban development: A reappraisal of our understanding. The Service Industries Journal, 25(4): 447-460.

JANČÁK, V., ERETOVÁ, V., HRABÁK, J. (2019): The Development of Agriculture in Czechia after the Collapse of the Eastern Bloc in European Context. In: Bański, J. et al. [eds.]: Three Decades of Transformation in the East-Central European Countryside (pp. 55-71). Cham, Springer.

KEEBLE, D; TYLER, P. (1995): Enterprising behaviour and the urban-rural shift. Urban Studies, 32(6): 975-997.

KALANTARIDIS, C. (2005): Global Integration and the Industrialization of the Countryside. In: Schmied, D. [ed.]: Winning and Losing. The Changing Geography of Europe's Rural Areas. Aldershot, Ashgate.

KOUTSKÝ, J. (2011): Staré průmyslové region - vývojové tendence, možnosti rozvoje. PhD Thesis. Ústí nad Labem, University of J. E. Purkyně.

KRUGMAN, P., VENABLES, A. J. (1995): Globalization and the Inequality of Nations. The Quarterly Journal of Economics, 110(4): 857-880.

KUNC, J. (2006): Historie a současnost průmyslové výroby na Moravě - regionální aspekty ekologického ohrožení krajiny. Národohospodářský obzor, 13(3): 42-49.

KVĚTOŇ, V., ŠAFR, K. (2019): Regional embeddedness, relatedness and inter-regional linkages among less developed regions in Central Europe. European Planning Studies, 27(5): 862-884.

LANG, R., FINK, M., KIBLER, E. (2014): Understanding place-based entrepreneurship in rural Central Europe: A comparative institutional analysis. International Small Business Journal, 32(2): 204-227.

LICHTER, D. T., BROWN, D. L. (2011): Rural America in an urban society: Changing spatial and social boundaries. Annual Review of Sociology, 37: 565-592.

MAJEROVÁ, V. (2017): The changing role of agriculture in the Czech countryside. In: Granberg. L., Kovách, I., Tovey, H. [eds.]: Europe's green ring (pp. 89-106). London, Routledge.

MARKUSEN, A. (1996): Sticky Places in Slippery Space: A Typology of Industrial Districts. Economic Geography, 72(3): 293-313.

MAYER, H., HABERSETZER, A., MEILI, R. (2016): Ruralurban linkages and sustainable regional development: The role of entrepreneurs in linking peripheries and centers. Sustainability, 8(8): 745.

MEIJERS, E. J., BURGER, M. J. (2017): Stretching the concept of 'borrowed size'. Urban Studies, 54(1): 269-291.

MILLS, B. K. (2002): Economic linkages in the rural economy: the case of producer services [PhD Thesis]. Plymouth, University of Plymouth.

MITCHELL M., ROBERTS D., COURTNEY P. (2005) Economic Linkages between Small Towns and Surrounding Rural Areas in Scotland. Final Report to the Scottish Executive. Edinburgh, Scottish Government.

MÜLLER, S., KORSGAARD, S. (2018): Resources and bridging: the role of spatial context in rural entrepreneurship. Entrepreneurship \& Regional Development, 30(1-2): 224-255.
NORTH, D. (1998): Rural industrialization. In: Ilbery, B. [ed.]: The Geography of Rural Change (pp. 161-188). London, Routledge.

NORTH, D., SMALLBONE, D. (1996): Small business development in remote rural areas: The example of mature manufacturing firms in Northern England. Journal of Rural Studies, 12(2): 151-167.

NORTH, D., SMALLBONE, D. (2006): Developing entrepreneurship and enterprise in Europe's peripheral rural areas: Some issues facing policy-makers. European Planning Studies 14(1): 41-60.

NOVÁK, V., JEŽÍKOVÁ, V. (2016): Hutnický a kovozpracující průmysl v České republice - data, ekonomická výkonnost, regionální zaměstnanost. In: Klímová, V., Žítek, V. [eds.]: XIX. mezinárodní kolokvium o regionálních vědách. Sborník příspěvků (pp. 247-254). Brno, Masarykova univerzita.

PARR, J. B. (2002): Agglomeration economies: ambiguities and confusions. Environment and planning A,34(4): 717-731.

PAVLÍNEK, P. (2004): Regional development implications of foreign direct investment in Central Europe. European urban and regional studies, 11(1): 47-70.

PAVLÍNEK, P., ŽENKA, J. (2016): Value creation and value capture in the automotive industry: Empirical evidence from Czechia. Environment and Planning A, 48(5): 937-959.

PAVLÍNEK, P., ŽIZŽALOVÁ, P. (2016): Linkages and spillovers in global production networks: firm-level analysis of the Czech automotive industry. Journal of Economic Geography, 16(2): 331-363.

PERKMANN, M. (2006): Extraregional linkages and the territorial embeddedness of multinational branch plants: evidence from the South Tyrol region in Northeast Italy. Economic Geography, 82(4): 421-441.

PERSKY, J., RANNEY, D., WIEWEL, W. (1993): Import Substitution and Local Economic Development. Economic Development Quarterly, 7(1): 18-29.

PILEČEK, J., JANČÁK, V. (2010): Je možné měřit sociální kapitál? Analýza územní diferenciace okresů Česka. Geografie, 115(1): 78-95.

PÍŠA, J., HRUŠKA, V. (2019): Entrepreneurial in-migration and rural development in Czechia: a challenge of integrating the local and extra-local in rural planning. Geographia Polonica, 92(3): 347-363.

ROMERO, I., SANTOS, F. (2007): Firm Size and Regional Linkages: A Typology of Manufacturing Establishments in Southern Spain. Regional Studies, 41(5): 571-584.

SLACH, O. (2011): Průmysl. In. Rumpel, P. (ed.): Komplexní regionální marketing periferního rurálního regionu Jesenicko (pp. 95-99). Plzeň, Aleš Čeněk.

SOHN, J. (2004): Do birds of a feather flock together? Economic linkage and geographic proximity. Annals of Regional Science, 38: 47-73.

SONN, J. W., LEE, D. (2012): Revisiting the branch plant syndrome: Review of literature on foreign direct investment and regional development in Western advanced economies. International Journal of Urban Sciences, 16(3): 243-259.

SÝKORA, L., OUŘEDNÍČEK, M. (2007): Sprawling postcommunist metropolis: commercial and residential suburbanisation in Prague and Brno, the Czech Republic. 
In: Razin, E. et al. [eds.]: Employment Deconcentration in European Metropolitan Areas: Market Forces versus Planning Regulations (pp. 209-233). Dordrecht, Springer.

SWINNEN, J. L. DRIES, L., MATHIJS, E. (2001): Constraints on employment growth and development in rural areas in transition countries: analysis and policy implications. Paper presented at the $73^{\text {rd }}$ European Association of Agricultural Economists seminar, Ancona, Italy.

ŠIMON, M. (2011): Kontraurbanizace: chaotický concept? Geografie, 116(3): 231-255.

ŠŤASTNÁ, M., KNIEZKOVÁ, T., NÁPLAVOVÁ, M. (2011): Embedding of rural businesses in the South Moravian Region. European Countryside 3(3): 198-207.

TAVARES, T. A., YOUNG, S. (2006): Sourcing patterns of foreign-owned multinational subsidiaries in Europe. Regional Studies, 40(6): 583-600.

The Time Now (2020): The calculator of distances [online]. Available at: http://cs.thetimenow.com/distancecalculator.php

TOUŠEK, V. ŠERÝ, O. (2013): Změny v rozmístění zpracovatelského průmyslu v období 1989 až 2011. In: Sborník příspěvku z Výroční konference České geografické společnosti "Nové výzvy pro geografii" (pp. 294-306). Brno, Masarykova univerzita.

WOODS, M. [ed.] (2005): Rural geography: processes, responses and experiences in rural restructuring. London, Sage Publication.

WOODS, M. (2013): Regions engaging globalization: A typology of regional responses in rural Europe. Journal of Rural and Community Development. 8(3): 113-126.
VAISHAR, A., ŠŤASTNÁ, M. (2019): Development of the Czech Countryside after 1990: Causes and Consequences. In: Bański J. etal. [eds.]: Three Decades of Transformation in the East-Central European Countryside (pp. 99-116). Cham, Springer.

ŽENKA, J., NOVOTNÝ, J., CSANK, P. (2014): Regional competitiveness in Central European countries: in search of a useful conceptual framework. European Planning Studies, 22(1): 164-183.

ŽENKA, J., PAVLÍNEK, P. (2013): Český automobilový průmysl v globálních produkčních sítích: regionální souvislosti rozvoje v období 1998-2008. Geografie, 118(2): 116-137.

ŽENKA, J., NOVOTNÝ, J., SLACH, O., KVĚTOŇ, V. (2015): Industrial specialization and economic performance: A case of Czech microregions. Norsk Geografisk TidsskriftNorwegian Journal of Geography, 69(2): 67-79.

ŽENKA, J., NOVOTNÝ, J., SLACH, O., IVAN, I. (2017): Spatial distribution of knowledge-intensive business services in a small post-communist economy. Journal of the Knowledge Economy, 8(2): 385-406.

ŽENKA, J., WELLISCH, S. (2019): Ekonomická výkonnost regionů v roce 2014 [Map] [online]. In: Atlas rozvoje venkova. Scale 1:1 250 000. Ostrava, University of Ostrava. Available at: https:/atlasvenkova.osu.cz/mapove-vystupy/

ŽENKA, J., PAVLÍK, A. (2019): Podíl zaměstnanosti ve zpracovatelském průmyslu ve venkovských oblastech na úrovni SO ORP v roce 2017 [Map] [online]. Atlas rozvoje venkova. Scale 1:1 250 000. Ostrava, Ostravská univerzita. Available at: https://atlasvenkova.osu.cz/mapove-vystupy/

\section{Please cite this article as:}

ŽENKA, J., ŠŤASTNÁ, S., PAVLÍK, A. (2021): The role of manufacturing in the development of rural regions: Evidence from a highly industrialised Moravian region. Moravian Geographical Reports, 29(1): 39-52. Doi: https://doi.org/10.2478/mgr-2021-0004 